\title{
Norges fjelde - det skrøbelige luftkastel
}

Af Søren Bom Nielsen, Geologisk Institut, Aarhus Universitet

\section{GeologiskNyt nr. 3 fra 2007 bragte} vi et indlæg af Søren Bom Nielsen om dannelsen af Norges fjelde. Dette indlæg resulterede i et modindlæg af Peter Japsen m.f. i nr. 5/07. Søren Bom Nielsen be- og forsvarer hér denne artikel i den fortsatte debat.

Mine ærede kolleger ved Geocenter Danmark, Peter Japsen et al. (herefter PJ et al.) har i det forrige nummer af GeologiskNyt (5/07) kommenteret mit tidligere indlæg om Norges fjelde og den videnskabelige proces. Ifølge PJ et al. har Norges fjelde og den østlige Nordsø oplevet markant tektonisk hævning i neogen tid. Mit indlæg derimod argumenterede for at det ville være værd at afprøve en ganske anden hypotese, nemlig den at det er den globale kænozoiske afkøling der har sat gang i erosionen af Kaledoniderne og således har simuleret tektonisk aktivitet.

Jeg har i mellemtiden haft lejlighed til at drøfte disse spørgsmål ganske indgående med Peter Japsen ved Nordisk Geologisk Vintermøde, og jeg tror man kan sige at vi har opnået en tilstand af gensidig respekterende uenighed, bl.a. om hvad man forstår ved en geologisk kendsgerning. Nedenstående kommentarer er derfor i første række henvendt til GeologiskNyts læsere for nærmere at belyse denne forskel i opfattelse af situationen.

\section{Landskabet i Sydnorge}

PJ et al.’s figur fra artiklen i nr. 5-2007 (figuren til højre) viser hvorledes rester af mesozoiske sedimenter beviser alderen af det landskab i Sydnorge der ligger mellem kysten og Hardangervidda. Det forholder sig imidlertid sådan at granskning af geologiske kort og udspørgning af geologer fra Norge og andre lande viser at der ikke eksisterer mesozoiske sedimenter mellem kysten og Hardangervidda som kan anvendes til at begrænse den mulige alder på det derværende landskab, og som kan bekræfte at landskabet er blevet tektonisk hævet fra en submarin position.

I henhold til mit begreb om geologiske kendsgerninger er det ikke tilstrækkeligt at mene at sedimenterne har været der, fordi det indebærer en antagelse om at der må være sket hævning, og står vi så ikke med en fuldbyrdet ringslutning? I stedet for at være en geologisk kendsgerning er PJ et al.'s opfattelse af landskabet i Sydnorge en fortolkning, der er rundet af den denudationskronologiske metode (en vis geomorfologisk tilgang til fortolkning og relativ datering af landskabselementer) til forståelse af landskaber.

Som jeg gør rede for i det følgende, er det således heller ikke en geologisk kendsgerning at Hardangervidda er et kænozoisk peneplan dannet ved havniveau som nu ved kænozoiske tektoniske kræfters mellemkomst befinder sig i en hævet position ca. 1 km over havniveau.

Kritik af denudationskronologisk metode PJ et al.'s tektoniske forståelse af landskabet i Sydnorge hviler på en ganske bestemt og stærkt kritiseret formodning om hvorledes relativt flade, højtliggende landskabselementer må være dannet - en opfattelse der går tilbage til Davis i slutningen af 1800 tallet,og som blev adopteret af den norske geolog Hans Reusch. Grundelementerne i den davisiske model (se citat af Chorley nedenfor) anvendes den dag i dag af den neogene tektoniske hævningsskole til at bevise eksistensen af vertikale tektoniske bevægelser.

Imidlertid mener mange at den denudationskronologiske metode ikke er særligt overbevisende (fx Phillips, 2002). For det første kan adskillige mere sandsynlige processer (ud over hævning af davisiske peneplaner, hvis de findes - Davis selv var bekymret) give anledning til at højtliggende landskabselementer udviser nutidig højdemæssig samhørighed. Således er klima, og i det skandinaviske tilfælde is og polare processer, en relevant alternativ mulighed. Dernæst vil alt der stikker op jo eroderes, så landskabselementer inklusiv flader overlever ikke i uændret form, og hvordan definerer man så overhovedet en flades eller et landskabs alder? I princippet er alderen vel 0 år fordi alting til stadighed eroderer? Det er således ikke holdbart at sige at et landskab har været beskyttet af sedimenter som nu er borte, for i det øjeblik overliggende materiale er eroderet bort, vil det underliggende blot erodere videre; det vil ikke stå og vente på at blive observeret som det landskab det engang var. Man kan fx stille sig selv det spørgsmål hvornår et eroderende landskab holder op med at have en bestemt alder (fx mesozoisk) for at få en ny?

Endelig vil overfladeprocesserne jo flytte rundt på masse og dermed give anledning til af- og pålastning af lithosfæren med deraf affødte vertikale isostatiske bevægelser passive men uigenkaldelige og allestedsnærværende effekter der straks virker tilbage på landskabets udvikling og modificerer eksisterende landskabselementer og producerer nye, der jo så fortolkes denudationskronologisk som tektonik. Her har vi vist at gøre med noget der minder om entydigt at ville bestemme $\mathrm{x}$ og $\mathrm{y}$ ud fra ligningen $\mathrm{x}+\mathrm{y}=$ 42. Svaret (dagens landskab) er kendt, men hvad er egentlig spørgsmålet? Hele miseren med den denudationskronologiske metode og de kvalitative sandheder den hviler på,

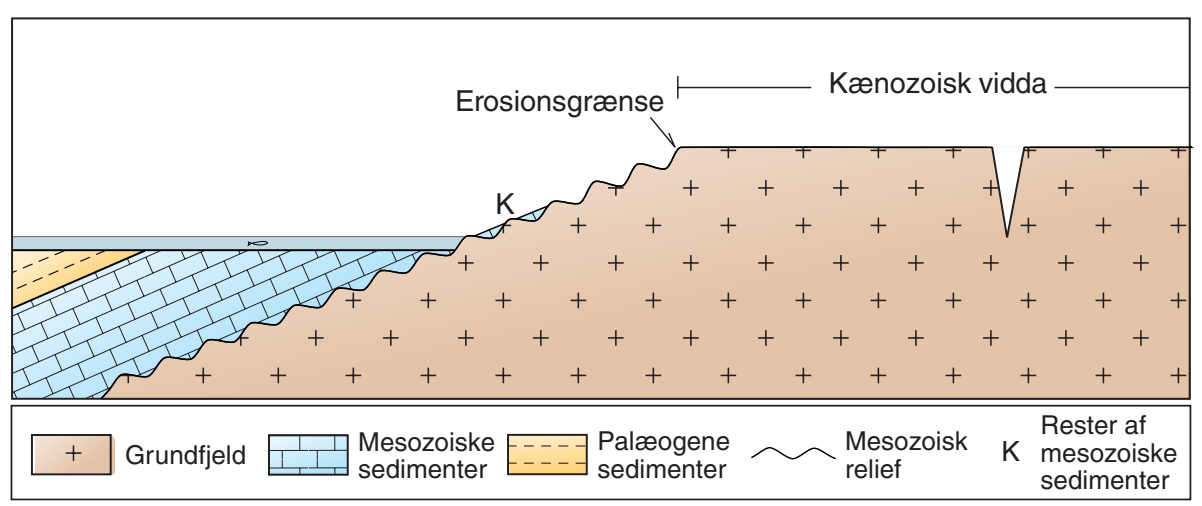

Denne figur blev bragt i forbindelse med debatindlegget om Norges fjelde i nr. 5-2007. (Grafik. Peter Japsen et al., 2007) 
er indfanget i følgende citat fra Chorley (1965):

"[denudation chronology] relying often upon highly ambiguous evidence, assumed like the cycle [Davis's cycle of erosion] the character of a highly stylized game indulged in by a free-masonry who after committing themselves to certain basic initial steps of faith (e.g. topographic flat means standstill; higher is older and lower is younger; uplift is generally discontinuous, etc.) reached conclusions which seem often to be more a product of the means of analysis rather than a physical reality. To adapt an expression of Sauer's [famous Berkeley geographer] (1925, p. 52), many studies of denudation chronology look like the products of men set out to 'bag their own decoys'."

Den noget sarkastiske sidste del af citatet om at denudationskronologernes resultater (frit oversat) er som når en vildtparade foranstaltes på basis af egne nedskudte lokkeænder, er ikke tiltænkt mine ærede kolleger, som jeg erkender er overbeviste om at denudationskronologiske fortolkninger leverer kendsgerninger. Det er det imidlertic langt fra alle der er, og citatet viser hvorledes bølgerne gik højt inden for det geomorfologiske fagområde i kølvandet på Davis’ cykliske landskabsteori.

\section{Det er videnskab}

Det er her på sin plads at nævne at der skam er skrevet flere artikler baseret på denudationskronologisk metodik vedrørende landskaber og deres fortolkning i Sydnorge og andre steder. Har disse lærde værker da ingen sandhedsværdi? Jeg vil gerne understrege at disse artikler er et fuldstændig
Roden under den høje topografi leverer opdrift som understøtter topografien. Så lange der er en opdriftsgivende rod vil topografien blive vedligeholdt og vcere tilgcengelig for erosion. Dette fenomen forlænger bjergkceders holdbarhed med en faktor 5 til 6. For hver kilometers scenkning af den gennemsnitlige topografiske højde skal der eroderes 5-6 km skorpe. (Grafik: forfatteren)
Erosion og aflastning

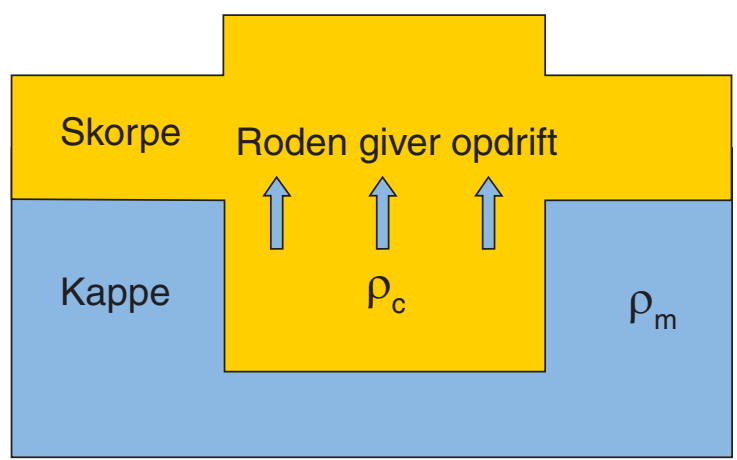

Peneplanisering går også ud over skorperoden
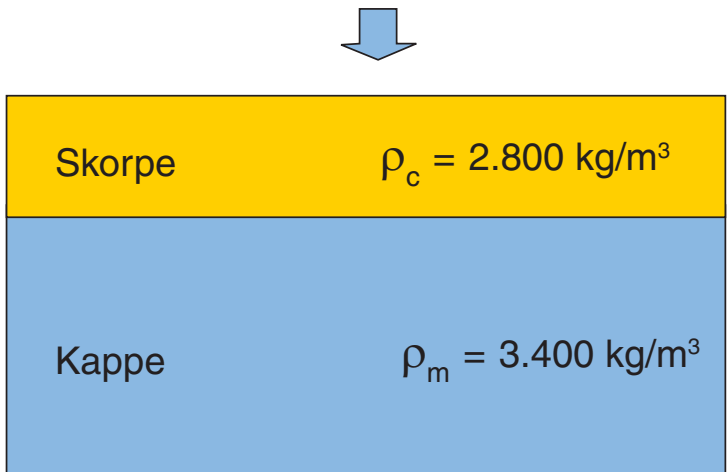

legalt udslag af den neogene tektoniske hævningsskoles normalvidenskabelige aktivitet (Kuhn, 1970), og at de som sådan da også sædvanligvis glat passerer gennem peer-review-systemet, der jo er normalvidenskabens strenge vogter.

Imidlertid bringer disse værker os ikke sandheden en millimeter nærmere fordi de hviler på en aldeles uverificeret antagelse (én meget lidt sandsynlig blandt adskillige mulige) om hvorledes de flade landskabselementer i Sydnorge er blevet til. Der er altså inden for den neogene tektoniske skole i allerhøjeste grad tale om at vcelge hvorledes man synes sydnorske landskabselementer bør fortolkes. Bemærk at der ikke eksisterer et enkelt gran af "smoking gun"-bevis for at dette valg er korrekt i Sydnorge. På dette bristefærdige luftkastel hviler altså den neogene tektonisk hævingshypotese. Men der er stadig tale om videnskab, for det er selvfølgelig tilladt at foretage kvalitative valg baseret på historiske forhold, synes, æstetik eller noget fjerde. Ingen kan vel undgå netop det.

Dog bør det i opklaringens interesse - og for at muliggøre kritisk stillingtagen og ikke føre uskyldige læsere, der ikke er orienteret ud i alle detaljer, bag lyset - gøres klart når der er tale om kvalitative vurderinger, der tilmed i dag som tidligere er stærkt presset af kritik. Et sådant forbehold kan man vist ikke umiddelbart læse ud af overskriften “geologiske kendsgerninger”.

\section{Begrebet den "falske skorperod"}

Idéen bag dette begreb er at på samme måde som en "falsk bakke" (fx Himmelbjerget) er blevet til ved at omgivende materiale er fjernet, er den "falske skorperod" kun synlig fordi skorpe-kappegrænsen (Moho) ligger mindre dybt rundt om roden pga. riftingprocesser i omgivelserne (Oslo-riften og offshore). Roden kan altså ikke gøre for at den findes; den er blot en geometrisk størrelse overhovedet uden funktion i forhold til topografien.

Jeg forstår godt at den neogene hævningsskole forsøger at dissociere sig fra roden, for den er virkelig en alvorlig sten i skoen. I modsætning til det skandinaviske skjold som sådan, er skorpen under Kaledoniderne forbundet med høj topografi og ekstra negativ Bouguer-tyngde. Det står enhver frit at forvisse sig herom. Der er således uomtvisteligt et masseunderskud under overfladen som i henhold til Arkimedes' velkendte princip holder topografien oppe (tænk på et isbjerg), et fundamentalt forhold som Kaledoniderne deler med alle mulige andre foldekæder rundt omkring (Alperne, Appalacherne, Ural osv.) (figuren ovenfor). Den kontinentale lithosfære er simpelthen ikke stærk nok til at holde den slags topografi svævende i fravær af opdrift under topografien. Beregninger viser at med fornuftige antagelser om massefylder i skorpe og kappe må størstedelen af det opdriftsgivende masseunderskud henføres til 
skorpen under topografien. Ellers passer det ikke med tyngdeanomaliens dybde og horisontale udstrækning. Endvidere viser vore målinger fra Sydnorge, at jo højere topografien er, jo dybere ligger Moho; altså jo mere opdrift, jo højere topografi. Skorpen under Kaledonidernes høje topografi fungerer altså som det vi forstår ved en skorperod. Der er desværre ingen sære overraskelser i forholdet mellem topografi, tyngdeanomali og skorpetykkelse. I tilgift bekræfter nye af os uafhængige seismologiske målinger (poster ved Nordisk Geologisk Vintermøde ved Richard England, University of Leicester, UK) $i$ et profil midt over Norge hvor topografien er lavest at der selv her tilsyneladende er en lidt dybere Moho (en rod), der hvor topografien er højest. At roden i Sydnorge også er gjort ekstra geometrisk synlig af omgivende rift-processer betyder ikke at denne kvalitet som rod kan ønskes bort.

Det er som sagt forbundet med uhyre vanskeligheder ikke at lade denne skorperod gå helt tilbage til Kaledonidernes dannelse i silur tid. Faktisk er den denudationskronologiske fortolkning af landskabet i Sydnorge den eneste "observation" overhovedet som ikke er forenelig med denne antagelse. Skulle nemlig topografien have været borteroderet for at producere Hardangervidda som et peneplan ved havniveau ville også roden til dels være blevet elimineret, for så længe der er en opdriftsgivende rod, er der også topografi at erodere (Arkimedes) (figuren på foregående side). Imidlertid er både roden og topografien til stede i dag. Jeg bringer i erindring at den neogene tektoniske hævning i henhold til overleveringen skal være dome-agtig og ikke tillader forkastninger i større stil eller magmatisk aktvitet, der jo heller ikke er observeret. Der er altså ingen plausible mekanisme der har kunnet give os roden tilbage i løbet af Kænozoikum.

PJ et al. nævner en del andre observationer der uomtvisteligt peger i neogen tektonisk retning, men om alle disse kan siges at der også her er tale om forhold der lader sig forstå på naturlig vis ved at erindre bl.a. 1) eksistensen af passive isostatiske belastningsprocesser som følge af erosion og aflejring,

2) kompaktion og diagenese af sedimenter ved begravelse,

3) et tidligere væsentligt højere havnivau end i dag,

4) Hævning fra Sen Kridt og midt Paleocæn langs Sorgenfrei-Tornquist Zonen og tilgrænsende områder, samt - ikke mindst 5) erosion ved basis af kvartære gletschere. Jeg erindrer om eksistensen af fx norske rende samt de i nordsøområdet allestedsnærværende begravede dale (tunneldale gravet ud i kænozoiske sedimenter med kvartært fyld). Og så skulle det jo være sært om ikke en forkastning her og der har bevæget sig en smule i forbindelse med den kænozoiske omrokering af overflademasse.

\section{At pleje sin hypotese}

Afslutningsvis er det måske på sin plads at erindre om hvorledes man i naturvidenskab bedst plejer sin hypotese. Som bekendt er det jo frygteligt vanskeligt at bevise noget som helst, for der vil altid være den mulighed at en ny type, eller blot mere nøjagtige observationer, en dag bringer en given hypotese i forlegenhed. Faktisk er det lige netop slet ikke muligt at bevise hypoteser, så det man kan gøre for at pleje sin hypotese er paradoksalt nok at forsøge at modbevise den, for jo flere konfrontationer med forskelligartede data hypotesen kan overleve, jo bedre er den.

Ironisk nok kan man derfor sige at det er gruppen bag projekt CENMOVE der virkelig nurser den neogene tektoniske hævningshypotese, nemlig ved at præsentere den for vidt forskellige skrappe afprøvninger i form af fænomenet skorperod, en korrelation mellem globale klimaskift og lithologi på Eocæn-Oligocæn-overgangen, samt en demonstration af at erosion ved basis af kvartære gletschere og tektoniske bevægelser langs Sorgenfrei-Tornquist
Zonen kan producere den fornødne overbegravelse og andre sedimentære strukturer langs kysten.

Disse CENMOVE-resultater, samt de mangfoldige problemer som gør den denudationskronologiske metode utroværdig, har for os eksponeret den neogene hævningshypoteses indlysende svagheder. Denne proces har ført os videre til projektet 3COLD (Climate Change and Caledonide Orogen Longterm Denudation), der mere målrettet skal undersøge hypotesen om klimakontrolleret denudation (via is og andre polare processer) af de nordatlantiske Kaledonider.

Vi har således efterhånden skudt os ind på at netop denne undersøgelse måske vil levere den ultimative pleje af den neogene hævningshypotese, og skulle denne omsorg i virkeligheden vise sig at være dødshjælp, ja så vil den neogene hævningshypotese glorværdigt gå over i historien som et skridt på vejen der fik os til at tænke os om, og den normalvidenskabelige aktivitet vil for en tid have fundet et lidt andet spor. Men vi kan jo ikke på forhånd vide hvad resultatet af denne afprøvning bliver. Vi har formuleret en hypotese og ønsker at afprøve den. Det er det bedste vi kan gøre, det er det vi skal gøre, og det var sådan set bare det jeg ville fortælle med mit første indlæg.

\section{Referencer:}

Chorley, R.J.,1965. A Re-Evaluation of the Geomorphic System of W M Davis. Chapter 2 in $R J$ Chorley and P Haggett (eds.), Frontiers in Geographic Teaching. London. Methuen.

Kuhn, T., 1970. The Structure of Scientific Revolutions. The University of Chicago Press, Chicago, 210 pp.

Phillips, J.D., 2002. Erosion, isostatic response, and the missing peneplains. Geomorphology 45, 225-241.

Efter forfatterens ønske er ny kommatering anvendt i denne artikel! 